\title{
NEONATAL PROPHYLAXIS: PREVENTION OF VITAMIN K DEFICIENCY HAEMORRHAGE AND NEONATAL OPHTHALMIA

\author{
NEONATALNA PROFILAKSA: PREPREČEVANJE KRVAVITEV ZARADI \\ POMANJKANJA VITAMINA K IN NEONATALNE OFTALMIJE
}

\author{
Anita JUG DOŠLER ${ }^{1 *}$, Petra PETROČNIK ${ }^{1}$, Ana Polona MIVŠEK ${ }^{1}$, Teja ZAKŠEK ${ }^{1}$ and Metka SKUBIC ${ }^{1}$
}

${ }^{1}$ University of Ljubljana, Faculty of Health Sciences, Zdravstvena pot 1, 1000 Ljubljana, Slovenia

\section{ABSTRACT}

\section{Keywords:}

neonatal prophylaxis, vitamin $\mathrm{K}$, newborn, ophtalmia, postpartum care

\section{IZVLEČEK}

Ključne besede: neonatana profilaksa, vitamin $K$, novorojenčki, oftalmija, nega postpartum
Introduction. The aim of the study was to explore two aspects of neonatal prophylaxis: the application of the vitamin $\mathrm{K}$ injection to the newborns and the prophylaxis against chlamydial and gonococcal eye infections, comparing Slovenian and Croatian practices.

Methods. A causal non-experimental method of quantitative empirical approach was used. The data was collected by means of predesigned questionnaires. The questionnaires were sent to 14 Slovenian and 32 Croatian birth hospitals. The data wasanalysed with descriptive statistics and the Kullback test.

Results. Vitamin $\mathrm{K}$ is applied to all newborns in 9 (out of 14) Slovene and 22 (out of 32) Croatian birth hospitals that returned the questionnaire. The prophylaxis against chlamydial gonococcal eye infections is applied to all newborns in 9 Slovene and 16 Croatian birth hospitals that offered answers to the questionnaire. The majority of Slovene and Croatian birth hospitals perform these procedures in the first hour after birth. The majority of Slovene birth hospitals still apply vitamin $\mathrm{K}$ in the gluteal muscle, whereas the majority of Croatian birth hospitals usually use the thigh as an injection site.

In Slovenia, 1 \% Targesin is used for the prophylaxis against chlamydial and gonococcal eye infections, whereas in Croatia the prevailing medicine is Erythromycin.

Conclusions. The possibility of oral vitamin $\mathrm{K}$ application should be offered to parents, and pain management in practice should be discussed. The form of written informed consent could be offered to parents. Health professionals should provide intimacy and exclude routine procedures in the first couple of hours after birth. However, more research is needed as delayed administration might be related to lower efficacy and, as a consequence of that, the safety of newborns is questionable.

Uvod. Namen opisane raziskave je bil proučiti določene vidike neonatalne profilakse: prakso aplikacije vitamina K novorojenčkom in profilakse proti klamidijski in gonokokni okužbi oči v slovenskih in hrvaških porodnišnicah.

Metode. $V$ raziskavi je bila uporabljena kavzalna neeksperimentalna metoda kvantitativnega empiričnega načina raziskovanja. Podatki so bili pridobljeni z vnaprej pripravljenimi vprašalniki, ki so bili razdeljeni v 14 slovenskih in 32 hrvaških porodnišnicah. Analiza podatkov je potekala z uporabo deskriptivne statistike in Kullbackovega preizkusa.

Rezultati. Ugotovili smo, da se praksa $v$ slovenskih in hrvaških porodnišnicah glede raziskovanih parametrov neonatalne profilakse razlikuje. Devet slovenskih porodnišnic (od vseh 14) in 22 hrvaških (od vseh 32), ki so sodelovale $v$ raziskavi, aplicira vitamin $K$ vsem novorojenčkom. Profilaktično zaščito proti klamidijskim ali gonokoknim očesnim okužbam pa izvajajo $v 9$ slovenskih in 16 hrvaških porodnišnicah (od vseh sodelujočih $v$ raziskavi). Večina slovenskih in hrvaških porodnišnic opravi oba posega $v$ prvi uri po rojstvu. Večina slovenskih porodnišnic aplicira vitamin $K v$ glutealno mišico, medtem ko je na Hrvaškem pogostejša aplikacija v stegensko mišico. $V$ slovenskih porodnišnicah pri apliciranju profilakse proti klamidijskim in gonokoknim okužbam oči prevladuje 1-odstotni Targezin, $v$ hrvaških pa Eritromicin.

Zaključek. Staršem je treba ponuditi možnost oralne aplikacije vitamina K. Dobro bi bilo spregovoriti o lajšanju bolečine ob tovrstnem posegu ter hkrati starše spodbuditi, da pisno in informirano privolijo $\checkmark$ poseg. Naloga zdravstvenih delavcev je, da družini $v$ prvih urah po porodu zagotovijo intimnost ter $v$ tem času poskusijo odložiti rutinske postopke. Za slednje pa so potrebne dodatne raziskave, saj lahko kasnejša administracija vodi $v$ manjšo učinkovitost profilakse in hkrati zmanjšuje varnost novorojenčkov.

*Corresponding author: Tel: +386 130011 85; E-mail: anita.jug@zf.uni-lj.si 


\section{INTRODUCTION}

Neonatal prophylaxis or prevention of neonatal diseases is an important contribution to the health condition of the general population and, consequently, reduces the costs of health services (1). In Slovenia, the routine first care of a newborn consists also of the neonatal eye prophylaxis, which usually includes the administration of eye drops. Apart from that, vitamin $\mathrm{K}$ is administered to newborns as a prophylaxis of haemorrhagic disease of the newborn, which has been carried out in Slovenia since 1987 (2). Both methods of neonatal prophylaxis are legally defined and mandatory in Slovenia (3), while, in Croatia, there is no formal regulation. Despite the evidence speaking in favour of the medicines used for neonatal prophylaxis, there are still certain disadvantages that can have an influence on the health and development of newborn children.

\subsection{Neonatal Ophthalmia}

Neonatal ophthalmia (NO), also known as conjunctivitis of the newborn, is the most common eye infection that usually occurs in the first 28 days of newborn life $(4,5)$. In the past, the term NO was used merely for the infections with Neisseria gonorrhoea, whereas today a number of other pathogens can be the cause of neonatal conjunctivitis (4). Neonatal prophylaxis was first mentioned around 1800 by a German obstetrician Carl Créde, who first described the prophylaxis of NO with silver nitrate and reported a dramatic decrease of gonococcal NO (8-10). Together with their development, silver nitrate was replaced by other antibiotics. However, the term 'Créde's prophylaxis' maintained in the literature (10).

\subsubsection{Aetiology and Incidence}

The causes of NO may be infective or non-infective (e.g. chemical, mechanical).The infective causes can be a consequence of sexually or non-sexually transmitted bacteria or viruses and can be seen more frequently in developing countries (11). The commonest bacterial sexually transmitted infections are caused by Neisseria gonorrhea and Chlamidia trachomatis $(11,12)$. The progress of chlamydial infections is much slower and rarely leaves serious consequences to newborns when compared to gonococcal infections (13). Apart from that, chlamydial infections are the most common bacterial sexually transmitted infections in the world (9). Cervical chlamydia in pregnancy can increase the risk of preterm birth and preterm rupture of membranes. A transmission of infect from a mother to a newborn child can occur during a vaginal labour, and can result as NO or pneumonitis in the newborn. In the case of a mother, it can also induce postpartum endometritis (14). The infection with Neisseria gonorrhoea can cause corneal ulcers and, consequently, lead towards blindness $(4,7)$. Despite a relatively high prevalence of prophylaxis throughout the world, NO can still be problematic since its incidence varies from 2-23\% in different countries (12).

\subsubsection{Prophylaxis}

Due to complications, such as visual loss, that result from Chlamydia trachomatis and Neisseria gonorrhoea infections, many countries are practising routine ocular prophylaxis in newborns with different agents (12).

\section{Silver Nitrate}

A solution of $1 \%$ silver nitrate has presented a very efficient prophylactic method for reducing gonococcal NO. However, its effect against chlamydial infections is very limited $(5-6,9)$ and it does not protect from all gonococcal infections (4).

\section{Targesin}

Targesin ${ }$ is a farmaceutic name for silver proteinacetyltannate, which contains organically bound silver. It has an antiseptic effect that is similar to silver nitrate together with its mode of action (15).

\section{Macrolides}

Macrolides are bacteriostatic, broad-spectrum ophthalmic antibiotics, binding with bacterial ribosomes to inhibit protein synthesis (16). Erythromycin, as the prototype of this class, is used in some European countries (16), and is highly practised in United States of America (USA) and Canada as a method of neonatal eye prophylaxis $(7,17)$. In comparison with silver nitrate, erythromycin and povidoneiodine are more efficient agents for the prophylaxis of NO caused by chlamydia (13). Azithromycin as one of the most recently approved ophthalmic antibiotics with a broad spectrum is particularly suited to ocular infections due to its unique pharmacokinetic profile allowing rapid tissue distribution, high tissue bioavailability and potent anti-inflammatory activities (16).

\section{Tetracycline}

$1 \%$ tetracycline ointment with antimicrobial effect was the only available topical treatment for many years (16). Tetracycline is an efficient prophylaxis against gonococcal infections and is active against Staphylococcus, Streptococcus and Pseudomonas. Moreover, it reduces the incidence of $\mathrm{NO}$ in the case of chlamydial infection, but does not prevent chlamydial colonisation in the nose and throat (5).

\section{Povidone-iodine}

A solution of $2.5 \%$ povidone-iodine is a non-toxic and inexpensive preparation. Apart from that, Meyer (18) 
outlines many advantages of this agent, including its positive effect against a number of microbes and the absence of antibiotic activity. However, it has to be acknowledged that its effect is still under research investigation in several studies (6).

\section{Fusidic Acid}

Fusidic acid is a bacteriostatic antibiotic that affects against N. Gonorrhoeae as well as against C. Trachomatis. It is a considerably recent agent in terms of neonatal eye prophylaxis, and its effect has to be further investigated in clinical trials (5).

\subsubsection{Global Guidelines and Situation in Slovenia and Croatia}

Neonatal eye prophylaxis is a mandatory procedure in Canada and most of the USA countries. Health professionals are legally obligated to perform the neonatal eye prophylaxis, and parents as citizens of these countries do not have the legal right to refuse this procedure. Therefore, certain authors emphasize that neonatal prophylaxis should be looked carefully in terms of ethics (7). A routine neonatal eye prophylaxis has been abandoned a few decades ago in numerous European countries, including United Kingdom, Sweden, Norway and Denmark $(7,13)$.

In accordance with the Slovenian Rules, amending the Rules on carrying out preventive health care at the primary level (3), neonatal eye prophylaxis is a mandatory intervention for all newborns in Slovenia. It has to be performed in the first 3 hours after birth with the application of $1 \%$ Targesin eye drops. In comparison, Croatia does not have the rules or the national guidelines on this specific procedure.

\subsection{Prevention of Vitamin K Deficiency Bleeding}

On the initiative of a number of authors, a disease formerly known as 'Haemorrhagic Disease of the Newborn (HDN)' has been renamed into a more precise term -'Vitamin K Deficiency Bleeding (VKDB)' (19-20). In the period from 1960 to 1980, most of the European countries initiated the intramuscular application of vitamin $\mathrm{K}$ to all newborns for prevention of VKDB (21). More than two decades ago, a controversial study came out in the United Kingdom, where intramuscular application of vitamin $\mathrm{K}$ was connected with a higher risk for the occurrence of childhood cancer, especially leukaemia (22). The study had a strong impact on Europe, as well as the whole world. The following papers showed the safety of vitamin $\mathrm{K}$ (23), but certain doubts regarding the intramuscular application of vitamin $\mathrm{K}$ remain.

\subsubsection{Aetiology}

The literature reports on three forms of VKDB: early, classic and late. Early VKDB occurs in the first 24 hours after birth, while classic VKDB can be seen between 1 and 7 days after birth. Late VKDB occurs from 2nd to 12 th week after birth, with a bleeding into intracranial space, skin, intestines, and is seen almost exclusively at breastfed babies $(24,25)$. VKDB occurs as a result of low levels of vitamin K-dependent clotting factors and prothrombin, since it plays an essential role in the synthesis of certain blood clotting factors (factor II, VII, IX, X) $(24,25)$.

\subsubsection{Prophylaxis with Vitamin $\mathrm{K}$}

Vitamin $\mathrm{K}$ is fat-soluble and can only be absorbed with the presence of bile salts (24). In adults, most of the vitamin $\mathrm{K}$ is absorbed from food and intestines, where intestinal bacteria are synthesizing vitamin $\mathrm{K}(26,27)$. The absorption of vitamin $\mathrm{K}$ is increased when an individual eats food that is rich with fat (28). Newborns have limited reserves of vitamin $\mathrm{K}$ and the passage of vitamin $\mathrm{K}$ through the placenta is minimal. Furthermore, intestines of a newborn are still sterile and do not synthesize vitamin $\mathrm{K}$. This means that the only source of vitamin $\mathrm{K}$ for newborns is mothers' milk, which contains very low levels of the vitamin in comparison to formula milk. Therefore, the risk for VKDB is higher in breastfed newborns $(24,29,30)$. There are two options for vitamin $\mathrm{K}$ application, including intramuscular and oral administration. Intramuscular application presents an invasive and painful method, which can induce muscular haematoma (24), osteomyelitis and abscess (31). It has to be acknowledged that pain can have long term consequences on neurological and cognitive development of newborns $(32,33)$. Although the oral application is a non-invasive method, the absorption of vitamin $\mathrm{K}$ can be reduced if a newborn is vomiting or expressing regurgitation after consuming vitamin $\mathrm{K}$ (24). Most of the authors who support the oral application advise several applications of vitamin $\mathrm{K}$ in lower doses (34, 35). Khambalia et al. (36) emphasize that doctors and midwives should leave the decision of the method of administration of vitamin $\mathrm{K}$ to the parents.

\subsubsection{Global Guidelines and Situation in Slovenia and Croatia}

Countries, such as New Zealand, United Kingdom and Ireland, recommend routine application of vitamin K to newborns, although there is no common agreement regarding the application and frequency of oral vitamin $\mathrm{K}$ administration $(28,37)$. The National Institute for Health and Care Excellence [NICE] (38) and the Department of Health (39) recommend intramuscular application of 
vitamin $\mathrm{K}$ for all newborns. In the case where parents refuse intramuscular application, the oral application should be suggested $(38,39)$. In accordance with the Slovenian Rules, amending the Rules on carrying out preventive health care at the primary level (3), prophylaxis of haemorrhagic disease has to be performed in the first 3 hours after birth with the application of $1 \mathrm{mg}$ intramuscular vitamin K. The republic of Croatia does not have any national guidelines for application of vitamin $\mathrm{K}$ to newborns.

This article presents results of the study that aimed to audit the current existing practice of vitamin $\mathrm{K}$ application to newborns after birth and neonatal eye prophylaxis. Slovenian and Croatian birth hospitals were studied with the assessment by clinical leaders of perinatal wards.

The authors were particularly interested in statistically significant differences between the countries. The questions of interest were:

1. How and when is the application performed?

2. Which newborns obtain the prophylaxis?

3. How are parents informed about the application?

\section{METHODS}

In this study, a causal non-experimental method of quantitative empirical approach was used. The data was collected by means of pre-designed questionnaires that were tested on a pilot sample of 15 people who were not included in the main study. By this, the understanding of the questions was tested. The survey was being performed from March to May 2013. The questionnaire consisted of 11 questions related to the previously outlined research questions. Factor analysis was used for determining the validity (\% of explained variance with the first factor) and reliability (\% of explained variance with common factors). It showed that our research instrument is in the limits of acceptable validity (the first factor explained $22.4 \%$ of variance) and reliability (the result of factor analysis revealed 3 factors that, all together, explain $60.1 \%$ of the variance).

The questionnaire was sent to 14 Slovenian (Kranj, Ljubljana, Jesenice, Trbovlje, Celje, Novo mesto, Maribor, Brežice, Šempeter, SlovenjGradec, Izola, MurskaSobota, Postojna, Ptuj) and 32 Croatian (Bjelovar, Čakovec, Dakovo, Dubrovnik, Gospić, Imotski, Karlovac, Knin, Koprivnica, Makarska, Metković, Našice, Nova Gradiška, Osijek, Ogulin, Pakrac, Požega, Pula, Rijeka, Sinj, Sisak, SlavonskiBrod, Split, Šibenik, Varaždin, Zadar, Vinkovci,
Virovitica, Vukovar, Zabuk, Zadar, Zagreb) labour ward clinical leaders. The response rate was $71 \%$ in Slovenia (10 returned and completed questionnaires) and $72 \%$ in Croatia (23 returned and valid questionnaires). The pattern was purposive. The participants were ensured a completely voluntary cooperation and anonymity. The study was approved by the Department of Midwifery on the Faculty of Health Sciences, University of Ljubljana. The data analysis was performed with the use of descriptive statistics, where Kullback $2 \hat{\imath}$ test was used for assessing the differences. The differences between the countries were accepted as statistically significant when the value $p$ was less or equal to 0.05 .

\section{RESULTS}

9 (90 \%) Slovenian and 22 (95.7 \%) Croatian maternity hospitals apply vitamin $K$ to all newborns (Table 1 ). Prophylaxis against chlamydial and gonococcal eye infections is applied to all newborns in at least 10 Slovenian (100\%) and 16 Croatian (69.9\%) maternity hospitals. $5(21.7 \%)$ Croatian maternity hospitals, estimated by the heads of birth hospital departments, do not apply prophylaxis against chlamydial and gonococcal eye infections to any newborn (Table 2). Despite the differences, which can detect the frequency distribution of data, statistical differences between Slovenia and Croatia were not traced in any of those variables.

Table 1. The application of vitamin $\mathrm{K}$.

\begin{tabular}{lcccc}
\hline $\begin{array}{l}\text { To which newborns } \\
\text { do you apply } \\
\text { vitamin K? }\end{array}$ & All & Other* & Total \\
\hline Slovenia & $\mathrm{f}$ & 9 & 1 & 10 \\
& $\mathrm{f}(\%)$ & 90.0 & 10.0 & 100.0 \\
Croatia & $\mathrm{f}$ & 22 & 1 & 23 \\
& $\mathrm{f}(\%)$ & 95.7 & 4.3 & 100.0 \\
Total & $\mathrm{f}$ & 31 & 2 & 33 \\
& $\mathrm{f}(\%)$ & 93.9 & 6.1 & 100.0 \\
Kullback $2 \hat{l}$ test $\quad(2 \hat{\imath}=0.361, \mathrm{~g}=1, \mathrm{p}=0.548)$ &
\end{tabular}

Legend: $\mathrm{g}$ - degrees of freedom, $\mathrm{p}$ - value of statistical significance, $f$ - frequency, $f(\%)$ - percentage,

* If parents of the newborn did not agree and did not sign an informed consent, the newborn did not get vitamin $\mathrm{K}$ application. 
Table 2. The application of prophylaxis against chlamydial and gonococcal eye infections.

\begin{tabular}{|c|c|c|c|c|c|c|}
\hline \multicolumn{2}{|c|}{$\begin{array}{l}\text { To which newborns do you apply } \\
\text { prophylaxis against chlamydial } \\
\text { and gonococcal eye infections? }\end{array}$} & All & Risk & None & Other* & Total \\
\hline \multirow[t]{2}{*}{ Slovenia } & $f$ & 10 & 0 & 0 & 0 & 10 \\
\hline & $f(\%)$ & 100.0 & 0.0 & 0.0 & 0.0 & 100.0 \\
\hline \multirow[t]{2}{*}{ Croatia } & $f$ & 16 & 1 & 5 & 1 & 23 \\
\hline & $f(\%)$ & 69.6 & 4.3 & 21.7 & 4.3 & 100.0 \\
\hline \multirow[t]{2}{*}{ Total } & $f$ & 26 & 1 & 5 & 1 & 33 \\
\hline & $f(\%)$ & 78.8 & 3.0 & 15.2 & 3.0 & 100.0 \\
\hline \multicolumn{7}{|c|}{ Kullback $2 \hat{\imath}$ test $\quad(2 \hat{l}=5,839, \mathrm{~g}=3, \mathrm{p}=0,120)$} \\
\hline
\end{tabular}

Legend: $g$ - degrees of freedom, $p$ - value of statistical significance, $f$ - frequency, $f(\%)$ - percentage

* Stands for all newborns, unless parents explicitly did not allow the application.

4 (40\%) birth hospitals in Slovenia and 10 (43.5\%) birth hospitals in Croatia, estimated by the heads of birth hospital departments, apply vitamin $\mathrm{K}$ in the first hour after birth. 4 (40\%) birth hospitals in Slovenia and 12 (52.2 \%) birth hospitals in Croatia apply vitamin $\mathrm{K}$ from one to three hours after birth, 1 birth hospital in Slovenia (10\%) and 1 in Croatia (4.3\%) apply vitamin K from three to 24 hours after birth (Table 3 ). Prophylaxis against chlamydial and gonococcal infections of the eye during the first hour after birth is applied by 4 (40\%) Slovenian and 9 (60\%) Croatian birth hospitals, while the prophylaxis of the 6 birth hospitals in Slovenia (60\%) and 6 birth hospitals in Croatia (40\%) is applied from one to three hours after birth (Table 4). These results do not show any statistically significant differences between Slovenia and Croatia.

Table 3. When do you apply vitamin K?

\begin{tabular}{|c|c|c|c|c|c|c|}
\hline \multicolumn{2}{|c|}{$\begin{array}{l}\text { When do you apply } \\
\text { the vitamin K? }\end{array}$} & \multirow{2}{*}{$\begin{array}{l}\text { In the first hour } \\
\text { after birth }\end{array}$} & \multirow{2}{*}{$\begin{array}{c}\text { From one to three } \\
\text { hours after birth }\end{array}$} & \multirow{2}{*}{$\begin{array}{c}\text { From three to } 24 \\
\text { hours after birth }\end{array}$} & \multirow{2}{*}{$\begin{array}{c}\text { Other* } \\
1\end{array}$} & \multirow{2}{*}{$\begin{array}{r}\text { Total } \\
10\end{array}$} \\
\hline Slovenia & $f$ & & & & & \\
\hline & $f(\%)$ & 40.0 & 40.0 & 10.0 & 10.0 & 100.0 \\
\hline \multirow[t]{2}{*}{ Croatia } & $f$ & 10 & 12 & 1 & 0 & 23 \\
\hline & $f(\%)$ & 43.5 & 52.2 & 4.3 & 0 & 100.0 \\
\hline \multirow[t]{2}{*}{ Total } & $f$ & 14 & 16 & 2 & 1 & 33 \\
\hline & $f(\%)$ & 42.4 & 48.5 & 6.1 & 3.0 & 100.0 \\
\hline Kullback & $(2 \hat{\imath}=2$ & $g=3, p=0.407)$ & & & & \\
\hline
\end{tabular}

Legend: $g$ - degrees of freedom, $p$ - value of statistical significance, $f$ - frequency, $f(\%)$ - percentage

* After a ceasarean section, or in case of complications during the first hour after birth, or the next morning, if the baby was born at night.

Table 4. When do you apply the prophylaxis against chlamydial and gonococcal eye infections?

\begin{tabular}{|c|c|c|c|c|}
\hline \multicolumn{2}{|c|}{$\begin{array}{l}\text { When do you apply the prophylaxis against } \\
\text { chlamydial and gonococcal eye infections? }\end{array}$} & \multirow{2}{*}{$\begin{array}{l}\text { In the first hour } \\
\text { after birth } \\
4\end{array}$} & \multirow{2}{*}{$\begin{array}{c}\text { From one to three hour } \\
\text { after birth } \\
6\end{array}$} & \multirow{2}{*}{$\begin{array}{c}\text { Total } \\
10\end{array}$} \\
\hline Slovenia & $f$ & & & \\
\hline & $f(\%)$ & 40.0 & 60.0 & 100.0 \\
\hline \multirow[t]{2}{*}{ Croatia } & $f$ & 9 & 6 & 23 \\
\hline & $f(\%)$ & 60 & 40 & 100.0 \\
\hline \multirow[t]{2}{*}{ Total } & $f$ & 13 & 12 & 33 \\
\hline & $f(\%)$ & 52 & 48 & 100.0 \\
\hline Kullback & $0.967, g=1, p=0.325)$ & & & \\
\hline
\end{tabular}

Legend: $g$ - degrees of freedom, $p$ - value of statistical significance, $f$ - frequency, $f(\%)$ - percentage 
In the case of intramuscular application of vitamin $\mathrm{K}$, the pain is relieved in 1 (10\%) birth hospital in Slovenia (with breastfeeding) and 5 (21.7\%) birth hospitals in Croatia (3 with breastfeeding, 1 with glucose, 1 with dressing). 9 (90 \%) birth hospitals in Slovenia and 18 (78.3 \%) in Croatia do not pay attention to the management of pain (Table 5). In the case of intramuscular application, 8 (80\%) Slovenian birth hospitals apply vitamin $\mathrm{K}$ in the gluteal muscle, while most of the Croatian birth hospitals (12, $52.5 \%$ ) apply vitamin $\mathrm{K}$ in the thigh muscle (Table 6).

Table 5. Pain management in the case of intramuscular application.

\begin{tabular}{lcccc}
\hline $\begin{array}{l}\text { Do you manage the pain } \\
\text { in the case of intramuscular } \\
\text { application? }\end{array}$ & No & Yes & Total \\
\hline Slovenia & $\mathrm{f}$ & 9 & 1 & 10 \\
& $\mathrm{f}(\%)$ & 90.0 & 10.0 & 100.0 \\
Croatia & $\mathrm{f}$ & 18 & 5 & 23 \\
& $\mathrm{f}(\%)$ & 78.3 & 21.7 & 100.0 \\
Total & $\mathrm{f}$ & 27 & 6 & 33 \\
& $\mathrm{f}(\%)$ & 81.8 & 18.2 & 100.0 \\
Kullback $2 \hat{\text { test }} \quad(2 \hat{\imath}=0.707, \mathrm{~g}=1, \mathrm{p}=0.401)$ &
\end{tabular}

Legend: $g$ - degrees of freedom, $p$ - value of statistical significance, $f$ frequency, $f(\%)$ - percentage
Table 6. The place for the vitamin $\mathrm{K}$ application (i.m. application).

\begin{tabular}{lcccc}
\hline $\begin{array}{l}\text { The place for the } \\
\text { vitamin K application }\end{array}$ & $\begin{array}{c}\text { Thigh } \\
\text { muscle }\end{array}$ & $\begin{array}{c}\text { Gluteal } \\
\text { muscle }\end{array}$ & Total \\
\hline Slovenia & $\mathrm{f}$ & 2 & 8 & 10 \\
& $\mathrm{f}(\%)$ & 20.0 & 80.0 & 100.0 \\
Croatia & $\mathrm{f}$ & 12 & 11 & 23 \\
& $\mathrm{f}(\%)$ & 52.2 & 47.8 & 100.0 \\
Total & $\mathrm{f}$ & 14 & 19 & 33 \\
& $\mathrm{f}(\%)$ & 42.4 & 57.6 & 100.0 \\
Kullback $2 \hat{l}$ test $\quad(2 \hat{\imath}=3.138, \mathrm{~g}=3, \mathrm{p}=0.076)$ & \\
\hline
\end{tabular}

Legend: $g$ - degrees of freedom, $p$ - value of statistical significance, $f$ frequency, $f(\%)$ - percentage

A half (of all 10) Slovenian birth hospitals (5, 55.6\%) and the maximum of Croatian birth hospitals (18, $85.7 \%)$ do not apply vitamin $\mathrm{K}$ per os (Table 7). In Croatia (23, $100 \%$ ), in all birth hospitals, parents can choose between intramuscular and oral application. In Slovenia, this is possible only in 4 (40\%) birth hospitals (Table 8 ). Between Slovenia and Croatia we traced a statistically significant difference in the regime of the oral vitamin $\mathrm{K}$ application $(2 \hat{\imath}=8.068, g=3, p=0.045)$ and also in the method of the application $(2 \hat{\imath}=10.916, \mathrm{~g}=1, \mathrm{p}=0.001)$.

Table 7. The regime of the oral vitamin $\mathrm{K}$ application.

\begin{tabular}{|c|c|c|c|c|c|c|}
\hline $\begin{array}{l}\text { What is } \\
\text { the regi } \\
\text { applicat }\end{array}$ & $\begin{array}{l}\text { birth hospital } \\
\text { he oral vitamin } \mathrm{K} \\
\text { os? }\end{array}$ & $\begin{array}{c}\text { We do not apply } \\
\text { the vitamin K } \\
\text { per os }\end{array}$ & $\begin{array}{l}\text { In a single } \\
\text { dose of } 1 \mathrm{mg} \\
\text { immediately }\end{array}$ & $\begin{array}{l}1 \mathrm{mg} \text { immediately } \\
\text { after birth and } \\
\text { the same dose one }\end{array}$ & Other* & Total \\
\hline Slovenia & $f$ & 5 & 1 & 2 & 1 & 9 \\
\hline & $f(\%)$ & 55.6 & 11.1 & 22.2 & 11.1 & 100.0 \\
\hline Croatia & $f$ & 18 & 3 & 0 & 0 & 21 \\
\hline & $f(\%)$ & 85.7 & 14.3 & 0 & 0 & 100.0 \\
\hline Total & $f$ & 23 & 4 & 2 & 1 & 30 \\
\hline & $f(\%)$ & 76.7 & 13.3 & 6.7 & 3.3 & 100.0 \\
\hline Kullback & $(2 \hat{\imath}=8.068, g=3$, & $0.045)$ & & & & \\
\hline
\end{tabular}

Legend: $g$ - degrees of freedom, $p$ - value of statistical significance, $f$ - frequency, $f(\%)$ - percentage

* Meaning $0.2 \mathrm{mg}$ orally in the first three hours after birth. 
Table 8. Parents choosing the way of the application.

\begin{tabular}{llccc}
\hline $\begin{array}{l}\text { Can parents choose } \\
\text { between intramuscular } \\
\text { and oral application? }\end{array}$ & Yes & No & Total \\
\hline Slovenia & $\mathrm{f}$ & 4 & 6 & 10 \\
& $\mathrm{f}(\%)$ & 40.0 & 60.0 & 100.0 \\
Croatia & $\mathrm{f}$ & 0 & 23 & 23 \\
& $\mathrm{f}(\%)$ & 0 & 100.0 & 100.0 \\
Total & $\mathrm{f}$ & 4 & 29 & 33 \\
& $\mathrm{f}(\%)$ & 12.1 & 87.9 & 100.0 \\
Kullback 2î test & $(2 \hat{\imath}=10.916, \mathrm{~g}=1, \mathrm{p}=0.001)$ & \\
\hline
\end{tabular}

Legend: $g$ - degrees of freedom, $p$ - value of statistical significance, $f$ - frequency, $f(\%)$ - percentage

Statistically significant differences between the two countries were also found in the sort of a medicine used against gonococcal and chlamydial infection in a newborn $(2 \hat{\imath}=11.816, g=3, p=0.008)$. In 8 Slovenian birth hospitals $(80 \%)$, the targesin drops are dominating (Targezin). In 3 Croatian birth hospitals (21.4\%), Erythromycin dominates (Table 9).

In most of Slovenian birth hospitals $(6,66.7 \%)$ and most of Croatian birth hospitals (9, 39.1\%), parents are informed about the procedure of the vitamin $\mathrm{K}$ application, but only 1 (11.1\%) birth hospital in Slovenia and $3(13.0 \%)$ birth hospitals in Croatia obtain the written consent from parents (Table 10). Providing parents with the information
Table 9. The medicine used against gonococcal and chlamydial infection in newborns.

\begin{tabular}{|c|c|c|c|c|c|c|}
\hline \multicolumn{2}{|c|}{$\begin{array}{l}\text { Which sort of } \\
\text { a medicine do } \\
\text { you use against } \\
\text { gonococcal } \\
\text { and chlamydial } \\
\text { infection in } \\
\text { newborns? }\end{array}$} & Targesin & $\begin{array}{l}\text { Erythro- } \\
\text { mycin }\end{array}$ & \multirow[t]{2}{*}{$\begin{array}{c}\text { Tetra- } \\
\text { cycline } \\
\\
0\end{array}$} & \multirow[t]{2}{*}{$\begin{array}{c}\text { Other* } \\
\\
1\end{array}$} & \multirow[t]{2}{*}{$\begin{array}{r}\text { Total } \\
\\
10 \\
\end{array}$} \\
\hline Slovenia & $f$ & 8 & 1 & & & \\
\hline & $f(\%)$ & 80.0 & 10.0 & 0.0 & 10.0 & 100.0 \\
\hline \multirow[t]{2}{*}{ Croatia } & $f$ & 2 & 3 & 1 & 8 & 14 \\
\hline & $f(\%)$ & 14.3 & 21.4 & 7.1 & 57.1 & 100.0 \\
\hline \multirow[t]{2}{*}{ Total } & $f$ & 10 & 1 & 5 & 1 & 24 \\
\hline & $f(\%)$ & 41.7 & 16.7 & 4.2 & 37.5 & 100.0 \\
\hline
\end{tabular}

Legend: $\mathrm{g}$ - degrees of freedom, $\mathrm{p}$ - value of statistical significance,

$f$ - frequency, $f(\%)$ - percentage

* Tobrex, sulfonamide preparation.

about the application of medicaments against gonococcal and chlamydial eye infection is a situation which is quite similar in both countries - in $60 \%$ only, birth hospitals inform parents about the intervention, in Croatia even less frequently (Table 11).

Table 10. Informing parents about the vitamin $\mathrm{K}$ application.

\begin{tabular}{|c|c|c|c|c|c|c|}
\hline $\begin{array}{l}\text { Do you } i \\
\text { the vita }\end{array}$ & $\begin{array}{l}\text { nts about } \\
\text { cation? }\end{array}$ & $\begin{array}{l}\text { Parents are } \\
\text { informed and }\end{array}$ & $\begin{array}{l}\text { Parents are } \\
\text { informed and }\end{array}$ & $\begin{array}{l}\text { Parents are } \\
\text { informed }\end{array}$ & $\begin{array}{l}\text { None of } \\
\text { the above }\end{array}$ & Total \\
\hline Slovenia & $f$ & 1 & 2 & 6 & 0 & 9 \\
\hline & $f(\%)$ & 11.1 & 22.2 & 66.7 & 0.0 & 100.0 \\
\hline Croatia & $f$ & 3 & 4 & 9 & 7 & 23 \\
\hline & $f(\%)$ & 13.0 & 17.4 & 39.1 & 30.4 & 100.0 \\
\hline Total & $f$ & 4 & 6 & 15 & 7 & 32 \\
\hline & $f(\%)$ & 12.5 & 18.8 & 46.9 & 21.9 & 100.0 \\
\hline
\end{tabular}

Legend: $g$ - degrees of freedom, $p$ - value of statistical significance, $f$ - frequency, $f(\%)$ - percentage 
Table 11. Informing parents about the medicine aplication against gonococcal and chlamydial eye infection.

\begin{tabular}{|c|c|c|c|c|c|c|}
\hline \multicolumn{2}{|c|}{$\begin{array}{l}\text { Do you inform parents about } \\
\text { the medicine aplication } \\
\text { against gonococcal and } \\
\text { chlamydial eye infection? }\end{array}$} & \multirow{2}{*}{$\begin{array}{c}\text { Parents are } \\
\text { informed and } \\
\text { they signed } \\
\text { a consent } \\
2\end{array}$} & \multirow{2}{*}{$\begin{array}{c}\text { Parents are } \\
\text { informed and } \\
\text { they gave an oral } \\
\text { consent }\end{array}$} & \multirow{2}{*}{$\begin{array}{c}\begin{array}{c}\text { Parents are } \\
\text { informed }\end{array} \\
6\end{array}$} & \multirow{2}{*}{$\begin{array}{c}\text { None of } \\
\text { the above }\end{array}$} & \multirow{2}{*}{$\begin{array}{r}\text { Tota } \\
\\
0\end{array}$} \\
\hline Slovenia & $f$ & & & & & \\
\hline & $f(\%)$ & 20.0 & 20.0 & 60.0 & 0.0 & 0.0 \\
\hline \multirow[t]{2}{*}{ Croatia } & $f$ & 2 & 2 & 6 & 6 & 6 \\
\hline & $f(\%)$ & 12.5 & 12.5 & 37.5 & 37.5 & 37.5 \\
\hline \multirow[t]{2}{*}{ Total } & $f$ & 4 & 4 & 12 & 6 & 6 \\
\hline & $f(\%)$ & 15.4 & 15.4 & 46.2 & 23.1 & 23.1 \\
\hline \multicolumn{7}{|c|}{ Kullback $2 \hat{\imath}$ test $\quad(2 \hat{\imath}=6.921, \mathrm{~g}=3, \mathrm{p}=0.074)$} \\
\hline
\end{tabular}

Legend: $g$ - degrees of freedom, $p$ - value of statistical significance, $f$ - frequency, $f(\%)$ - percentage

\section{DISCUSSION}

The results of our study showed that there are some differences regarding the prophylaxis of haemorrhagic disease and neonatal ophthalmia between Slovenian and Croatian birth hospitals. A relatively high percentage of Croatian birth hospitals does not perform the prophylaxis against neonatal ophthalmia to newborns. However, the foreign literature is not unified about this procedure. According to Darling (7), many European countries gave up the neonatal eye prophylaxis decades ago. It is well known that preparations used for the neonatal eye prophylaxis are aggressive $(6,7)$. The Canadian paediatric society (4) estimates that silver nitrate causes chemical conjunctivitis in 50-90\%, and can, therefore, make the first contact and attachment between a mother and a child more difficult $(40,41)$. Another disadvantage of antibiotic medicines (Erythromycin, Tetracycline) is early exposure of newborns to antibiotics, which can lead to allergic reactions. The widespread use of antibiotics can lead to resistance (7) and to chemical conjunctivitis (11). Despite that, some authors claim that neonatal eye prophylaxis should become a worldwide routine procedure (42). The plausible explanation for this is probably the fact that the occurrence of these infections is not stable, but rather increasing $(43,44)$.

In the case of intramuscular application, the majority of Slovenian birth hospitals apply vitamin $\mathrm{K}$ in the gluteal muscle. Although gluteal injections should be avoided in Slovenian birth hospitals, the change in practice has not been adapted by the time of the questionnaire administration. Some authors emphasize that thigh muscle is more appropriate for administering intramuscular vitamin $\mathrm{K}$ to newborns (45). Moreover, the majority of Slovenian birth hospitals do not relieve newborns of the pain before the intramuscular vitamin $\mathrm{K}$ administration. Croatian birth hospitals relieve pain before the procedure to more children that the Slovenian ones, which is also in accordance with the latest guidelines of Italian association of neonatologists for proceduring pain in the newborn. The use of preparations for pain relievement is considerably restricted in newborns. When choosing a non-pharmacological preparation, a dermal anaesthetic ointment is recommended (33). It has to be acknowledged that pain can present a great stress for a newborn (46, 47).

In Croatia, parents can choose between intramuscular and oral application of vitamin $\mathrm{K}$ for their newborns in birth hospitals. This is in accordance with some authors that emphasize the informed decision regarding the vitamin $\mathrm{K}$ administration should be undertaken by parents (36). On the other hand, NICE (38) and Department of Health (39) recommend intramuscular application of vitamin K, but allow free choice for the oral administration. Despite that, Italian Association of Neonatologists recommends the oral administration of vitamin $\mathrm{K}$ to all exclusively breastfed newborns (48). It should also be outlined that both of the methods improve the status of coagulation in the newborn (24). Several small amounts of oral vitamin $\mathrm{K}$ application should successfully substitute the intramuscular application (49). There are certain individuals that advocate the meaning of physiological management of the third stage of labour together with late cord clamping. According to this theory, a newborn receives an increased blood volume and, by that, higher level of clotting factors (28). On the other hand, it is highly unlikely that this single procedure, by itself, would help raise vitamin K levels enough to prevent VKDB (19). The American Academy of Pediatrics recommends a single intramuscular dose of vitamin $\mathrm{K}$ and allows a delayed administration $(50,51)$. According to Dekker (52), vitamin $\mathrm{K}$ should be given after the first feeding is completed, but it should be administered within 6 hours after birth. 
The situations in Slovenia and Croatia are similar regarding the application of the medicines against gonococcal and chlamydial eye infection. The results show low parental involvement in decision-making regarding the procedures of neonatal prophylaxis. Most of the procedures are still performed without a real informed consent. Due to the overloaded health professionals on the labour wards, parents could get more information about the prophylactic procedures of their newborn in pregnancy. This could also be provided by means of suitable information leaflets (28). By this, parents could get more time to make an informed consent and to seek for additional information. The majority of Slovenian and Croatian birth hospitals apply the prophylaxis in the first hour after birth, although this time should be dedicated exclusively to parents and their newborns, to establish the first contact in the first two hours after birth (53). Therefore, some procedures of the administration of the newborn could be postponed and performed after the first 'golden' hour after birth. However, the delay should be first evaluated from the aspect of the safety of the newborn, as delayed administration might be related to lower efficacy.

\section{CONCLUSION}

The results of this study show the situation in Slovenian birth hospitals related to the practice at the time of the distribution of the questionnaire. Due to updated recommendations of the Paediatric Association of Slovenia, recent deviations could be seen in the current practice. However, the study showed that the majority of Slovenian birth hospitals do not offer the possibility of oral vitamin $\mathrm{K}$ application, whereas this is possible in Croatia. By that, the differences of the incidence of VKDB should be researched, as well as the possibility of oral vitamin $\mathrm{K}$ application offered to parents. Pain management in the intramuscular vitamin $\mathrm{K}$ application is rare and it should be discussed in practice. On the other hand, the prophylaxis against NO is more frequent in Slovenia than Croatia, but, in Croatia, antibiotic medicines are used more frequently. Parents are informed about the procedures both in Slovenia and Croatia, but the written informed consent is still rare. The form of written informed consent would be a sensible decision. A relatively high percentage of newborns obtain the prophylaxis in the first one, or in the first three, hours after birth. Health professionals should provide intimacy for the new family and exclude routine procedures of the first care of the healthy, mature newborn, in the first couple of hours after birth. However, more research is needed, as delayed administration might be related to lower efficacy, which questions the safety of the newborn.

\section{CONFLICTS OF INTEREST}

The authors declare that no conflicts of interest exist. The work is original; it has not been previously published in print or electronic format, and it is not under consideration by another publisher or electronic medium; it has not been previously transferred, assigned, or otherwise encumbered; and the authors have full power to grant such rights. With respect to the results of this work, the manuscript of this, or substantially similar, content will not be submitted to any other journal until the review process in your journal has been officially completed.

\section{FUNDING}

We have no financial interests in this manuscript. The study was not financed.

\section{ETHICAL APPROVAL}

Authors confirm that the procedures followed in the manuscript were in accordance with the ethical standards of the journal and responsible institution in which scientists work.

\section{REFERENCES}

1. Shiel WC, Stoeppler MC, Lee D, Marks JW, Mathur R. Webster's new world medical dictionary. 3rd ed. New Jersey: Wiley Publishing, 2008.

2. Lapajne Dekleva T. Vitamin K: katero je prvo zdravilo, ki ste ga dobili? Gea. Available Sept 9, 2014 from:

3. http://www.mladinska.com/gea/pretekle_stevilke/poljudna_ znanost $/$ clanek?aid=2868.

4. Pravilnik o spremembah in dopolnitvah pravilnika za izvajanje preventivnega zdravstvenega varstva na primarni ravni. Ur I RS $31 / 2005$.

5. Canadian Paediatric Society. Recommendations for the prevention of neonatal ophthalmia. Paediatr Child Health 2002; 7: 480-3.

6. Zuppa AA, D'Andrea V, Catenazzi P, Scorrano A, Romagnoli C. Ophthalmia neonatorum: what kind of prophylaxis? J Matern Fetal Neonatal Med 2011; 24: 769-73.

7. Ganatra HA, Zaidi AKM. Neonatal infections in the developing world. Semin Perinatol 2010; 34: 416-25.

8. Darling EK. Is mandatory neonatal eye prophylaxis ethically justified? a case study from Canada. Public Health Ethics 2011. Available Aug 14, 2014 from: http://www2.cfpc.ca/local/user/files/\%7BCB070CB9FA33-4167-B903-EC10519A4EE6\%7D/phe\%202011\%20article.pdf.

9. Dunn PM. Dr Carl Crede (1819-1892) and the prevention of ophtalmia neonatorum. Arch Dis Child Fetal Neonatal Ed 2000; 83: 158-9.

10. Kakar S, Bhalla P, Maria A, Rana M, Chawla R, Mathur NB. Chlamydia trachomatis causing neonatal conjuctivitis in a tertiary care center. Indian J Med Microbiol 2010; 28: 45-7.

11. Schmidt A. Gonorrheal ophthalmia neonatorum: historic impact of Crede's eye prophylaxis. In: Schroten H, Wirth S, editors. Pediatric infectious diseases revisited. Basel: Birkhäuser, 2007: 95-115. 
12. Matejcek A, Goldman RD. Treatment and prevention of ophthalmia neonatorum. Can Fam Physician 2013; 59: 1187-90.

13. Gul SS, Jamal M, Khan N. Ophtalmia neonatorum. J Coll Physicians Surg Pak 2010; 20: 595-8.

14. Darling EK, McDonald H. A Meta-analysis of the efficacy of ocular prophylactic agents used for the prevention of gonococcal and chlamydial ophthalmia neonatorum. J Midwifery Womens Health 2010; 55: 319-27.

15. Gupta NK, Bowman CA. Managing sexually transmitted infections in pregnant women. Womens Health 2012; 8: 313-21.

16. Krämer I, Haber $M$, Duis A. Formulation requirements for the ophthalmic use of antiseptics. In: Kramer A., Behrens-Baumann W. Antiseptic prophylaxis and therapy in ocular infections: principles, clinical practice and infection control. Basel: Karger, 2002.

17. Bremond-Gignac D, Chiambaretta F, Milazzo S. An European perspective on topical ophthalmic antibiotics: current and evolving options. Ophthalmol Eye Dis 2011; 24: 29-43.

18. Hammerschlag MR. Chlamydial and gonococcal infections in infants and children. Clin Infect Dis 2011; 53(Suppl 3): S99-102.

19. Meyer D. Ophthalmia neonatorum prophylaxis and the 21st century antimicrobial resistance challenge. Middle East Afr J Ophthalmol 2014; 21: 203-4.

20. Shearer MJ. Vitamin K deficiency bleeding (VKDB) in early infancy. Blood Rev 2009; 23: 49-59.

21. Sutor $\mathrm{AH}$, von Kries $\mathrm{R}$, Cornelissen EA, McNinch AW, Andrew M. Vitamin $\mathrm{K}$ deficiency bleeding (VKDB) in infancy. Thromb Haemost 1999; 81: 456-61.

22. Hey E. Vitamin K - what, why, and when. Arch Dis Child Fetal Neonatal Ed 2003; 88: F80-3.

23. Golding J, Greenwood R, Birmingham K, Mott M. Childhood cancer, intramuscular vitamin $\mathrm{K}$, and pethidine given during labour. $\mathrm{Br}$ Med J 1992; 305: 341-6.

24. Ross JS, Davies SM. Vitamin K prophylaxis and childhood cancer. Med Pediatr Oncol 2000; 34: 434-7.

25. Puckett RM, Offringa $M$. Prophylactic vitamin $\mathrm{K}$ for vitamin $\mathrm{K}$ deficiency bleeding in neonates. Cochrane Database Syst Rev 2000; 4: CD002776.

26. Takahashi D, Shirahata A, Itoh S, Takahashi Y, Nishiguchi T, Matsuda $\mathrm{Y}$. Vitamin $\mathrm{K}$ prophylaxis and late vitamin $\mathrm{K}$ deficiency bleeding in infants: fifth nationwide survey in Japan. Pediatr Int 2011; 53: 897901.

27. Lippi G, Franchini M. Vitamin K in neonates: facts and myths. Blood Transfus 2011; 9: 4-9.

28. Warren M, Miller A, Traylor J, Sidonio R, Morad A, Christensen D. et al. Late vitamin $\mathrm{K}$ deficiency bleeding in infants whoose parents declined vitamin K prophylaxis- Tennessee, 2013. MMWR Morb Mortal Wkly Rep 2013; 62: 901-2.

29. Harvey B. Newborn vitamin K prophylaxis: developments and dilemmas. Br J Midwifery 2008; 16: 516-9.

30. Van Winckel M, De Bruyne R, Van De Velde S, Van Biervliet S. Vitamin K, an update for the paediatrician. Eur J Pediatr 2009; 168: 127-34.

31. Shah F, Khan MA, Khan J, Munir A, Karim R. Hemorrhagic disease of the newborn: clinical presentation and response to treatment with vitamin K. Gomal J Med Sci 2013; 11: 101-4.

32. Jafarzadeh M, Mohammadzadeh A, Farhat AS, Keramati MR, Khajedaluei $M$. The comparison effect of oral and intramuscular injection vitamin $\mathrm{K}$ on PT and APTT in neonates. Int $\mathrm{J}$ Hematol Oncol 2008; 2: 74-8

33. Kashaninia Z, Sajedi F, Rahgozar M, Noghabi FA. The effect of cangaroo care on behavioral responses to pain of an intramuscular injection in neonates. J Spec Pediatr Nurs 2008; 13: 275-80.

34. Lago P, Garetti E, Merazzi D, Pieragostini L, Ancora G, Pirelli A. et al. Guidelines for procedural pain in the newborn. Acta Paediatr 2009; 98: $932-9$.
35. Stiefel A. Das gesunde Neugeborene. In: Geist C, Harder U, Stiefel A, editors. Hebammenkunde. 4th ed. Stuttgart: Hipocrates Verlag, 2007: 552-3.

36. Tobi H, Schirm E, Verdegaal AM, de Jong LTW. Pharmacotherapy in the perinatal period - an exploratory study in midwifery. Pharm World Sci 2001; 23: 224-6.

37. Khambalia AZ, Roberts CL, Bowen JR, Nassar N. Maternal and infant characteristics by mode of vitamin $\mathrm{K}$ prophylaxis administration. $\mathrm{J}$ Pediatr Child Health 2012; 48: 665-8.

38. Darlow BA, Phillips AA, Dickson NP. New Zealand surveillance of neonatal vitamin K deficiency bleeding (VKDB): 1998-2008. J Pediatr Child Health 2011; 47: 460-4.

39. National Institute for Health and Care Excellence. Postnatal care: routine postnatal care of women and their babies: guidance, 2006. Available Aug 12, 2014 at: http://www.nice.org.uk/guidance/cg37/ chapter/guidance.

40. Calman K, Moores Y. Vitamin $\mathrm{K}$ for newborn babies. London: Department of Health, 1998.

41. Johnson PJ. Vitamin K prophylaxis in the newborn: indications and conroversies. Neonatal Netw 2013; 32: 193-9.

42. Johnston PGB, Flood K, Spinks K. The newborn child. 9th ed Edinburgh: Churchill Livingstone, 2008.

43. Caligaris LSA, Medina NH, Durkin SR, Haro-Munoz E, Chinen NH Assessment of the current ocular health practices within units in the City of São Paulo, Brazil. Ophthal Epidem 2010; 17: 333-7.

44. Klavs I, Kustec T, Kastelic Z. Spolno prenesene okužbe v Sloveniji: letno poročilo 2011. Ljubljana: Inštitut za varovanje zdravja, 2012: 4-11.

45. Centers for Disease Control and Prevention. Cases of sexually transmitted diseases reported by state health departments and rates per 100,000 population, United States, 1941-2012. Available Sept 8, 2014 from: http://www.cdc.gov/std/stats12/tables/1.htm.

46. Johnson R, Taylor W. Skills for midwifery practice. 3rd ed. London: Churchill Livingstone, 2009.

47. Martín-Lopez JE, Carlos-Gil AM, Rodríguez-López R, Villegas-Portero $\mathrm{R}$, Luque-Romero L, Flores-Moreno $\mathrm{S}$. Prophylactic vitamin $\mathrm{K}$ for vitamin $\mathrm{K}$ deficiency bleeding of the newborn. Farmacia Hospitalaria (English Ed.) 2011; 35: 148-55.

48. Ipema $\mathrm{HJ}$. Use of oral vitamin $\mathrm{K}$ for prevention of late vitamin $\mathrm{K}$ deficiency bleeding in neonates when injectable vitamin $\mathrm{K}$ is not available. Ann Pharmacother 2012; 46: 879-83.

49. Ciantelli M, Bartalena L, Bernardini M, Biver P, Chesi F, Boldrini A. et al. Late vitamin $\mathrm{K}$ deficiency bleeding after intramuscular prophylaxis at birth: a case report. J Perinatol 2009; 29: 168-9.

50. National Health and Medical Research Council. Joint statement and recommendations on vitamin $\mathrm{K}$ administrationto newborn infants to prevent vitamin $\mathrm{K}$ deficiency bleeding in infancy. Canberra: Commonwealth Australia, 2010.

51. American Academy of Pediatrics. Controversies concerning vitamin $\mathrm{K}$ in the newborn. Available Jan 5, 2015 from: http: //pediatrics. aappublications.org/content/112/1/191.full.

52. American Academy of Pediatrics. Policy statement - AAP publications retired and reaffirmed. Pediatrics 2009; 124: 845.

53. Dekker R. Evidence for the vitamin $\mathrm{K}$ shots in newborns. Available Jan 5, 2015 at: http://evidencebasedbirth.com/evidence-for-thevitamin-k-shot-in-newborns/

54. Bratanič B, Fidler N, Hlastan Ribič C, Poličnik R, Širca Čampa A, Kosem R. et al. Smernice zdravega prehranjevanja za dojenčke. Ljubljana: Ministrstvo za zdravje RS, 2010 